\title{
Extremisme gezien vanuit de Dialogical Self Theory
}

\author{
Frans Wijsen \& Hubert Hermans
}

\begin{abstract}
Sinds de Tweede Wereldoorlog hebben verschillende EU-lidstaten te maken gehad met gewelddadig extremisme (RAF, ETA), al dan niet vermengd met religie (IRA, RMS), ${ }^{1}$ maar islamitisch extremisme was zeldzaam tot in de jaren negentig. Herinneringen aan de aanslag op het olympisch dorp in München van 1972, waar twee Israëlische olympiërs werden gedood door acht Palestijnse extremisten, vervagen in vergelijking met recente aanslagen in Parijs, Brussel, Nice, Berlijn, Londen, Stockholm enzovoort.

In deze bijdrage willen we een ontwikkeling laten zien in de zogeheten Dialogical Self Theory (DST) die van belang kan zijn voor het begrijpen van en omgaan met extremisme. De DST is vooral bekend uit de persoonlijkheidsleer en de therapeutische toepassing ervan in de Zelfkonfrontatiemethode (ZKM). Maar recentelijk is de theorie uitgebreid naar de samenhang tussen persoonlijkheid en verschijnselen als globalisering en democratisering. ${ }^{2}$
\end{abstract}

Extremisme is geen gemakkelijk concept om te definiëren. Er zijn veel verwante concepten in omloop, zoals fundamentalisme, radicalisme, fanatisme, militarisme en terrorisme, die niet altijd duidelijk afgebakend zijn. Extremisme kan gedefinieerd worden als een houding (mening, gevoel, gedragsdispositie) van een persoon of groep die ver verwijderd is van wat als normaal of gewoon wordt beschouwd. ${ }^{3}$ Extremisme is een benaming voor opvattingen of gedragingen waarin medemensen of groepen in de samenleving worden gezien als anders, vreemd of vijandig. Het is gebaseerd op exclusief denken dat verschillende wereldbeelden als onverenigbaar beschouwt. Er is geen gemeenschappelijk fundament of ontmoetingspunt tussen hen. In die zin leiden extremistische opvattingen of gedragingen vaak tot uitsluiting en maatschappelijke polarisatie.

1 De RAF (Rote Armee Fraktion) was een links-extremistische beweging die vooral streed tegen uitingen van kapitalisme; de ETA (Euskadi Ta Askatasuna) was een onafhankelijkheidsbeweging die een socialistische Baskische staat wilde vestigen; de IRA (Irish Republican Army) was een beweging die streefde naar de vereniging van Noord-Ierland met het (katholieke) Ierland; de RMS (Republik Maluku Selatan) is een beweging die onafhankelijkheid van de Molukken van (het overwegend islamitische) Indonesië nastreeft.

2 Een populairwetenschappelijke samenvatting van deze ontwikkeling in de theorie is te vinden in het onlangs verschenen boek van H. Hermans, Bedreigde psychodiversiteit: Pleidooi voor een innerlijke democratie, Old Turnhout/Den Bosch: Gompel \& Svacina 2018. Later in dit artikel zullen we verwijzen naar het wetenschappelijk onderzoek waarop de theorie gebaseerd is.

3 Zie A. Bartoli, P. Coleman \& H. Burgess, Dealing with extremists, Boulder: Conflict Information Consortium, University of Colorado 2017. www.berondintractability.org.essay/dealing-extrmists. geraadpleegd op 15 november 2017. 
De meeste verklaringen voor de opkomst van extremisme gaan uit van de groeiende diversiteit in hedendaagse Europese samenlevingen, debatten over nationale identiteit, de grenzen van de liberale democratie en de vraag hoe verschillende groeperingen met elkaar moeten omgaan. Deze bijdrage gaat uit van het verband tussen diversiteit, democratie en dialoog. Enerzijds wordt democratie bedreigd door extremisten die hun wil opleggen aan anderen, al dan niet met gebruik van geweld. Anderzijds wordt een gebrek aan democratie, in het bijzonder uitsluiting van groepen die 'vreemd' of 'anders' zijn, beschouwd als oorzaak van extremisme. Een voorbeeld van uitsluiting van groepen die 'vreemd' of 'anders' zijn, zijn de wereldwijde maatregelen ter bestrijding van gewelddadig extremisme (vaak kortweg aangeduid als Countering Violent Extremism) die niet zelden een inbreuk zijn op de rechten van burgers onder het mom van nationale veiligheid. ${ }^{4}$ Geweld moet bestreden worden, maar de harde maatregelen treffen vaak grote groepen mensen die met dit geweld niets te maken hebben.

Deze bijdrage gaat voorts uit van de veronderstelling dat beleidsmakers beter in staat zijn om verschillende vormen van extremisme te voorspellen, te voorkomen en te bestrijden wanneer zij inzicht hebben in het verband tussen diversiteit, democratie en dialoog. We baseren ons op de Dialogical Self Theory, die volgens ons uniek is in haar vermogen om bruggen te bouwen. ${ }^{5}$ De DST is gebruikt in diverse studies naar diversiteit ${ }^{6}$ en wordt recentelijk toegepast in studies naar democratie. $^{7}$

\section{Wij-zij-denken}

Sinds de aanslagen van 11 september 2001 op het Wereldhandelscentrum in New York en de daaropvolgende war against terror is de dominante benadering van extremisme gebaseerd op de dichotomie tussen 'wij' en 'zij'. Zoals toenmalig president Bush zei: 'Ieder land, iedere regio moet een keuze maken: je bent met ons, of je bent met de terroristen.' Hiermee draaide hij het oude Bijbelse adagium 'wie niet tegen ons is, is voor ons' (Lucas 9:50) om.

De opmerking van Bush komt mede voort uit het paradigma van de clash of civilizations. Volgens Samuel Huntington is het niet meer het politieke en economische belang, maar eerder een verlangen naar culturele hegemonie dat op de voorgrond staat in internationale conflicten. $\mathrm{Na}$ het verdwijnen van het oost-west-

4 P. Romaniuk, Does CVE Work? Lessons Learned from the Global Effort to Counter Violent Extremism, New York: Global Center on Cooperative Security 2015.

5 H.J.M. Hermans \& A. Hermans-Konopka, Dialogical Self Theory: Positioning and Counter-Positioning in a Globalizing Society, Cambridge, VK: Cambridge University Press, 2010.

6 M. Buitelaar, 'Constructing a Muslim Self in a Post-migration Context: Continuity and Discontinuity with Parental Voices', in: M. Buitelaar \& H. Zock (red.), Religious Voices in Self-Narratives: Making Sense of Life in Times of Transition, Berlijn/Boston: De Gruyter 2013, p. 241-274; J. König, Moving Experience. Complexities of Acculturation (diss.), Universiteit voor Humanistiek 2012; F. Stock, Speaking of Home. Home and identity in the multivoiced narratives of descendants of Moroccan and Turkish migrants in the Netherlands (thesis), University of Groningen 2014.

7 H.J.M. Hermans e.a., 'Fields of tension in a boundary- crossing world: Towards a democratic organization of the self', Integrative Psychological and Behavioral Sciences2017, p. 505-535. 
conflict is er nu een tendens tot culturele reorganisatie van de wereldgemeenschap, waarin religies, meer dan enige andere sociale factor, een grote rol spelen. Economische belangen zouden een tweede rol spelen bij dit proces van herschikking. Volgens hem liggen culturen waarin religie een vitale rol speelt aan de basis van alle uitbarstingen van geweld. ${ }^{8}$

Er zijn in de visie van Huntington acht culturele zones en iedere zone belooft de eigen economische belangen te beschermen. Voor Huntington zijn er drie culturele grootmachten die de loop van de toekomstige geschiedenis van de mensheid zullen bepalen: de christelijke cultuur in het Westen, de islamitische cultuur in het Midden-Oosten en de confucianistische cultuur in Azië. De vijf andere culturele samensmeltingen zullen partij kiezen in overeenstemming met de ontwikkelingen in de hiervoor genoemde grote culturele zones, maar ze zullen een cruciale rol spelen bij het bepalen van de aard van sociaal en politiek weefsel in hun onderlinge wisselvalligheden. Het zijn de Japanse cultuur, de hindoeïstische cultuur uit India, de orthodoxe cultuur uit Rusland, de Latijns-Amerikaanse cultuur en (mogelijk) de Afrikaanse cultuur. Deze culturele entiteiten beïnvloeden de internationale handel en diplomatieke betrekkingen van vandaag zo nadrukkelijk, aldus Huntington, dat het definiëren van de identiteit van de partner sine qua non is voordat ze een waardevolle transactie tussen de naties aangaat.

Huntingtons theorie is meer een vaststelling dat deze botsing zou plaatsvinden dan dat het daar een verklaring voor geeft. Niettemin speelt Huntington in op andere theorieën die daar wel verklaringen voor geven. De belangrijkste is de Social Identity Theory (SIT). ${ }^{9}$ In wezen gaat deze theorie terug op de functionele etnocentrisme theorie van Wilhelm Sumner, die stelt dat 'the relation of comradeship and peace in the we-group and that of hostility and war towards othersgroups are correlative to each other' ${ }^{10}$ De SIT heeft de volgende uitgangspunten: (1) de persoonlijke identiteit wordt afgeleid van het groepslidmaatschap; (2) mensen streven naar een positief zelfbeeld en verlangen naar een positieve sociale identiteit; (3) ze zijn zelfs bereid hun beeld van buitenstaanders te manipuleren om hun zelfbeeld op te poetsen. Alleen al de gedachte aan het bestaan van een andere groep, zelfs als er geen schaarste of belangenconflict is, versterkt de interne solidariteit en de identificatie met de eigen groep.

\section{Dialogical Self Theory}

Wie echter naar de feiten kijkt, ziet dat er veel interculturele en interreligieuze samenwerking is, en over het algemeen genomen is de wereld nu vreedzamer dan

8 S. Huntington, The Clash of Civilizations and the Remaking of the World Order, New York: Simon \& Schuster 1996.

9 H. Tajfel, 'Social Categorization, Social Identity and Social Comparison', in: H. Tajfel (red.), Differentiation between groups, Londen: Academic Press 1978, p. 61-76; H. Tajfel \& J. Turner, 'The Social identity theory of intergroup behaviour', in: S. Worchel \& W. Austin (red.), Psychology of Intergroup Relations, Chicago: Nelson-Hall Publishers 1986, p. 7-24.

10 W. Sumner, Folkways. A study of the sociological importance of usages, manners, customs and morals, Boston/New York: Ginn and Company 1906, p. 2. 
ooit, ${ }^{11}$ de 'botsing der culturen'-retoriek ten spijt. Naast 'botsing van culturen' is er ook veel 'vermenging van culturen', of hybride culturen. ${ }^{12}$ De SIT levert geen verklaring voor dit verschijnsel. De DST echter wel. ${ }^{13}$ Deze theorie biedt de handvatten om te verklaren waarom mensen zich in religieuze en culturele identiteiten verschansen, maar ook waarom ze die grenzen overschrijden en vormen van samenwerking en -leving zoeken.

Het centrale idee van deze theorie is dat sociale processen, zoals dialoog en strijd om overheersing, die zichtbaar zijn in de samenleving in het algemeen ook plaatsvinden binnen het 'zelf', opgevat als een society of mind. Het zelf wordt niet beschouwd als een opzichzelfstaande entiteit, als een vaststaand gegeven waarvoor de samenleving slechts een bevorderende of belemmerende omgeving is, maar juist als een gegeven dat voortkomt uit sociale, historische en maatschappelijke processen. ${ }^{14}$

De theorie combineert twee concepten, zelf en dialoog. Doorgaans verwijst het concept 'zelf' naar iets 'innerlijks', iets wat plaatsvindt in de geest van het individu. 'Dialoog' wordt gewoonlijk geassocieerd met iets 'externs', processen die plaatsvinden tussen mensen die met elkaar communiceren. Het samengestelde concept 'dialogisch zelf overstijgt deze tweedeling door het externe naar het innerlijke te brengen en ook omgekeerd, door het innerlijke met het externe te verweven. De theorie beschrijft het zelf als een diversiteit aan relaties tussen verschillende 'ik-posities'. Ze gaat ervan uit dat de innerlijke samenleving wordt bevolkt, gestimuleerd en vernieuwd door ik-posities in ontwikkeling. Het onderlinge verband in de zelf-samenleving zorgt ervoor dat wordt afgestapt van de opvatting dat het zelf in zichzelf verwezenlijkt en ingekapseld is. Het omzeilt ook het idee van een 'zelf-loze samenleving' die niet in staat is haar voordeel te doen met de creativiteit van de individuele menselijke geest om bestaande sociale praktijken te vernieuwen.

De theorie van het dialogisch zelf staat niet op zichzelf in de sociale wetenschappen. $\mathrm{Zij}$ is voortgekomen uit het raakvlak tussen twee tradities: Amerikaans pragmatisme en Russisch dialogisme. Als zelftheorie is zij geïnspireerd door de klassieke formuleringen over de werking van het zelf door James en Mead. ${ }^{15} \mathrm{Als}$ dialogische theorie bouwt zij voort op de vruchtbare inzichten in dialogische processen van Bakhtin. ${ }^{16}$

11 S. Pinker, The better angels of our nature. The decline of violence in history and its causes, New York: Viking 2011; M. Marshall, Major episodes of political violence, University of Maryland: Centre for Systemic Peace 2016, www.systemicpeace.org/warlist/warlist.htm, geraadpleegd op 22 mei 2017.

12 U. Hannerz, Cultural complexity. Studies in the social organization of meaning, New York: Columbia University Press 1992; P. Burke, Cultural Hybridity, Cambridge: Polity 2009.

13 Zie H.J.M. Hermans \& T. Gieser, Handbook of Dialogical Self Theory, Cambridge, VK: Cambridge University Press 2010.

14 Zie ook P. Ricoeur, Oneself as another, Chicago: University of Chicago Press 1992; C. Taylor, 'The Dialogical Self, in: R. Goodman \& W. Fischer (red.), Rethinking Knowledge. Reflections across the disciplines, New York: State University of New York Press 1995, p. 57-66; A. Giddens, Modernity and self-identity. Self and identity in the late modern age, Cambridge: Polity Press 1991.

15 W. James, The principles of psychology (vol. 1), Londen: Macmillan 1890; G.H. Mead, Mind, self, and society, University of Chicago Press 1934.

16 M. Bakhtin, Problems of Dostoevsky's poetics, Minneapolis: University of Minnesota Press 1984. 
Het zelf wordt in deze theorie dus opgevat als de wisselende relatie tussen een veelheid van ik-posities. Een ik-positie kan gezien worden als de neerslag van een proces van positioneren. ${ }^{17}$ Het werkwoord 'positioneren' is een ruimtelijke term. Het verwijst naar het proces waarin het zelf noodzakelijk betrokken is als deel van een wereld waarin mensen elkaar en zichzelf plaatsen met behulp van de woorden 'hier' en 'daar'. Als een persoon zichzelf 'ergens' plaatst, zijn er altijd, expliciet of impliciet, andere posities bij betrokken, die liggen in de ruimte om ons heen of in de innerlijke metaforische ruimte van het zelf. In deze zin positioneer ik mijzelf als eens of oneens, als dol zijn op of een hekel hebben aan, of als nauw verwant met of fel tegen een ander of mijzelf.

Een belangrijk theoretisch voordeel van het woord 'positioneren' is dat het als een actief en als een passief werkwoord gebruikt kan worden. Vanaf onze geboorte zijn wij gepositioneerd door onze sociale omgeving (als jongen of meisje, als gekleurd of blank, als deel van een meerderheid of minderheid) en veel van onze actieve positionering kan beschouwd worden als een monologisch of dialogisch antwoord op deze invloeden. We raken betrokken in dialogen of monologen als deze posities een stem krijgen, die al dan niet gehoord wordt, al dan niet een antwoord krijgt en al dan niet de ruimte krijgt om zich uit te drukken.

In het dialogische zelf is zowel veelheid (aansluitend op het postmoderne model van het gefragmenteerde zelf) als eenheid (aansluitend op het moderne model van het uniforme zelf) een centraal concept. ${ }^{18}$ Daarom beoogt de theorie het begrip van eenheid en continuïteit te laten aansluiten op een concept van een zelf dat verschil, veelheid, tegenstrijdigheid en discontinuïteit erkent. Dit maakt het mogelijk om een rijke diversiteit aan verschijnselen in hun onderlinge verband te onderzoeken. In het begrip ik-positie worden veelheid en eenheid samengevoegd in een en dezelfde samengestelde term. Eenheid en continuïteit worden uitgedrukt door een 'ik'-, 'mij'- of 'mijn'-stempel te zetten op verschillende en zelfs tegenstrijdige posities in het zelf, waarmee wordt aangegeven dat deze posities worden ervaren als deel van het zelf in de uitgebreide zin van het woord (bijvoorbeeld: 'ik de ambitieuze', 'ik de angstige', 'mijn vader de optimist', 'mijn dierbare kinderen' en zelfs 'mijn irritante collega's'). Aangezien die verschillende posities worden 'toegeëigend' door een en dezelfde ik, mij of mijn ontstaan eenheid en continuïteit binnen die veelheid.

In een notendop veronderstelt de DST (1) dat het 'zelf' kan worden opgevat als een mini-maatschappij of een veelvoud van belichaamde ik-posities die elk hun eigen stem kunnen laten horen en waartussen dialogische relaties bestaan, en (2) dat het 'zelf 'in staat is om te wisselen tussen een veelvoud van ik-posities, zoals opgeroepen door verschillende, zelfs tegenstrijdige, situaties. Net zoals er machtsrelaties bestaan in de samenleving in het groot, zo kunnen sommige ikposities dominant worden ten opzichte van andere ik-posities in de society of mind. ${ }^{19}$ 
In het licht van deze theorie is de fundamentele vraag met betrekking tot extremisme waarom en onder welke voorwaarden sommige mensen niet langer in staat zijn om tussen de ene en de andere positie te wisselen? Waarom blijven ze vastzitten in een enkele positie en vergeten ze hun ander posities? Ofwel: waarom worden ze extreem? Het antwoord op deze vraag stelt ons in staat om andere vragen te beantwoorden, zoals: Kun je extremisme voorspellen? Kun je extremisme voorkomen? Kun je extremisme bestrijden ${ }^{20}$

\section{Waarom worden mensen extreem?}

Het dialogische zelf is in principe democratisch georganiseerd. ${ }^{21}$ Net als in de politiek is de dialogische mens in staat om compromissen te sluiten tussen verschillende, zelfs tegenstrijdige ik-posities. Extremisten zijn doorgaans ondemocratisch ingesteld. Net zoals in het ondemocratische zelf één stem andere stemmen overschreeuwt, zo ook leggen extremisten hun wil op aan anderen.

Men kan deze stelling echter ook omdraaien. Omdat de dominante stem in de maatschappij de perifere stemmen tot zwijgen brengt, worden deze extreme stemmen nog extremer. Dit is vaak het geval met mensen die anders zijn dan de meerderheid, hetgeen wederzijds vreemdheid en vervreemding oproept, en soms zelf vijandigheid. De perifere stem wordt door de dominante stem gemarginaliseerd. De perifere stem wil echter gehoord worden en komt in verzet.

In een onderzoek naar de positionering van Indonesische moslims in Nederland bleek dat zij het moeilijk vinden om een goed moslim én een goed burger te zijn. De dominante stem in Nederland zegt dat een goede burger 'modern' is, en je kunt niet 'modern' en 'moslim' zijn; die twee ik-posities sluiten elkaar uit. Om in Nederland te integreren moet je minder moslim zijn. Van weeromstuit zeiden sommige Indonesische moslims dat ze om te integreren juist meer moslim moesten zijn, puur moslim, bevrijd van culturele ballast en tradities. ${ }^{22}$

Het is bekend dat moslimse jongeren zich steeds meer identificeren met hun moslimse en/of etnische ik-positie, en een neiging hebben zich af te keren van de

20 Deze en andere vragen worden ook besproken door R. da Silva in haar boek Narratives of Political Violence. Life Stories of Former Militants, Londen/New York: Routledge 2019, p. 4. Het boek gaat over politiek geweld in Portugal en is geschreven vanuit het perspectief van de Dialogical Self Theory. Zie ook R. da Silva e.a., 'Disengagement from Political Violence and Deradicalization: A Narrative-Dialogical Perspective', Studies in Conflict \& Terrorism 2018, DOI: 10.1080/1057610X. 2018.1452709.

21 H.J.M. Hermans, Society in the Self: A Theory of Identity in Democracy, New York: Oxford University Press 2018, p. 45-104.

22 Zie F. Wijsen, 'Indonesian Muslim or World Citizen? Religious Identity in the Dutch Integration Discourse', in: F. Wijsen \& K. Von Stuckrad (red.), Making Religion: Theory and Practice in the Discursive Study of Religion, Leiden/Boston: Brill 2016, p. 225-238. 
Nederlandse samenleving. ${ }^{23}$ Zonder een eenduidige verklaring voor dit verschijnsel te willen geven is een reden die deze jongeren zelf geven dat ze zich in Nederland niet serieus genomen voelen ${ }^{24}$ en in toenemende mate gediscrimineerd worden. ${ }^{25}$

Aldus is de DST in staat zowel een verklaring te geven van het feit dat mensen van verschillende culturen en religies vreedzaam kunnen samenleven, als van de constatering dat moslimse jongeren, zoals iedere culturele groep die gemarginaliseerd wordt, hun oorspronkelijke identiteit verdedigen of versterken en mogelijk extreme denkbeelden ontwikkelen.

\section{Is extremisme te voorspellen?}

Een van de opvallende kenmerken van ervaringen met extremisten is dat de omgeving vaak niet merkt dat ze extreme denkbeelden ontwikkelen. ${ }^{26}$ Het zijn goede buren, echtgenoten, broers of collega's, en de buitenwereld reageert vaak verbaasd als ze overgaan tot geweld. Het voorspellen van extremisme is zeker geen gemakkelijke opgave. Wanneer we ervan uitgaan dat extremisme een attitude is die drie componenten heeft, ${ }^{27}$ dan kunnen we globaal de volgende indicatoren noemen:

1 Cognitie: mensen met extreme denkbeelden kunnen vaak moeilijk omgaan met cognitieve dissonantie en meervoudige betekenissen. Voor hen is de werkelijkheid eenduidig. Dissonantie tussen opvattingen of tussen opvattingen

23 Zie W. Huijnk, De religieuze beleving van Moslims in Nederland. Diversiteit en verandering in beeld, Den Haag: Sociaal en Cultureel Planbureau 2018. Zie ook W. Huijnk e.a. (red.), Werelden van verschil. Over de sociaal-culturele afstand en positie van migrantengroepen in Nederland, Den Haag: Sociaal en Cultureel Planbureau 2015; F. Geelhoed, Purification and Resistance. Glocal Meanings of Islamic Fundamentalism in the Netherlands (diss.), Erasmus University Rotterdam 2012; E. VisserVogel, Religious identity development of orthoprax Muslim adolescents in the Netherlands (diss.), University of Utrecht 2015.

24 Dit gevoel is niet geheel ongegrond. Maatschappelijke trends lijken te wijzen in de richting van toename van discriminatie. Zie o.a. I. van der Valk, Islamfobie en discriminatie, Amsterdam: Pallas Publications/Amsterdam University Press 2012, p. 115-116; Wetenschappelijke Raad voor het Regeringsbeleid, Identificatie met Nederland, Amsterdam: Amsterdam University Press 2007, p. 148-154.

25 Volgens recent onderzoek voelen Nederlandse moslims zich het vaker gediscrimineerd op religieuze gronden dan hun geloofsgenoten in andere EU-lidstaten. $30 \%$ van de Nederlandse moslims ervoer de afgelopen vijf jaar deze vorm discriminatie. Discriminatie op grond van afkomst is in éen EU-land hoger dan in Nederland. Zie European Union Agency for Fundamental Rights, Second European Union Minorities and Discrimination Survey. Muslims - Selected Findings, Luxemburg: Publications Office of the European Union 2017.

26 Op 27 september 2018 werd een mogelijk terroristische aanslag verijdeld en een mogelijk terroristische cel van zeven jonge manen opgerold. Hoewel de hoofdverdachte eerder veroordeeld was, waren de buurtgenoten en familieleden van de andere verdachten totaal verrast. Dit lijkt vaak het geval bij soortgelijke zaken. Zie ook J. van de Beek \& C. van Dyck, Sultan en de lokroep van de jihad, Amsterdam: Uitgeverij Balans 2017, een journalistiek boek over Sultan Berzel, de rustige ROC-student uit de Maastrichtse wijk het Wittevrouwenveld die een zelfmoordaanslag pleegde in Bagdad.

27 Bartoli, Coleman \& Burgess 2017. 
en gedrag proberen ze te verminderen. Ze kunnen moeilijk omgaan met strijdige ik-posities. ${ }^{28}$

2 Affectie: extremisten hebben vaak een gebrek aan vertrouwen in de politiek, instituties, rechtsorde. Ze begeven zich aan de flanken en zijn wars van compromissen. Het gebrek aan vertrouwen maakt dialogische relaties tussen personen en tussen tegenstrijdige ik-posities in het zelf moeilijk.

3 Gedragsdispositie: extremisten tenderen naar enkelvoudig groepslidmaatschap, met een duidelijk afbakening van de grenzen van 'binnen' en 'buiten'. Dit leidt tot een beperkt en gesloten positierepertoire. ${ }^{29}$

\section{Is extremisme te voorkomen?}

Zoals reeds gezegd, extremisme is een veelzijdig fenomeen dat overigens maar bij een zeer klein deel van de bevolking voorkomt. Sommigen leggen nadruk op ideologische invloeden, anderen op economische factoren. Als we ervan uitgaan dat er een correlatie bestaan tussen dialoog en democratie, ${ }^{30}$ dan is het vergroten van het democratische gehalte van individuele burgers en de samenleving als geheel een belangrijke voorwaarde voor het voorkomen van extremisme. Enerzijds is een bevordering van het democratische zelf in opvoeding en onderwijs vereist. ${ }^{31}$ Anderzijds gaat het om het democratiseren van de democratie. Democratische besluitvorming is niet gebaseerd op de helft plus één, maar op polyfonie, tolerantie voor oppositie en het realiseren van eenheid in verscheidenheid.

En als preventie niet lukt, is extremisme dan te bestrijden? Het antwoord op deze vraag is ja, maar het is niet eenvoudig. Er zijn goede voorbeelden van mensen die geradicaliseerd waren en die dit nu niet meer zijn. Over het algemeen heeft repressie of hersenspoeling niet veel zin. Vanuit het perspectief van de DST gaat het erom extremisten te helpen zichzelf en anderen te bekijken vanuit een helikopterperspectief en van daaruit tolerantie voor tegenstrijdige ik-posities te ontwikkelen.

Enig optimisme ontlenen we aan het feit dat de DST met succes gebruikt is in het Zuid-Afrika na de apartheid om de polarisatie tussen 'zwart' en 'blank' te verminderen. ${ }^{32}$ In deze context is de uitspraak van Ali Mazrui interessant, die de war

28 Selengut verklaart religieus geweld met een beroep op de theorie van cognitieve dissonantie. Zie C. Selengut, Sacred fury: Understanding religious violence, Walnut Creek, CA: Altamira Press 2003.

29 Zie verder L. Manne.a., 'Weerbaarheid tegen radicalisering en extremisme: Welke factoren bepalen of iemand weerbaar is tegen extremistische invloeden en zijn deze factoren meetbaar?' Magazine Nationale Veiligheid en Crisisbeheersing 2015, 4, p. 24-25.

30 Hermans 2018, p. 45-104; Hermans 2018, p. 95-118.

31 Zie F. Meijers \& H. Hermans (red.), The dialogical self in education. A multicultural perspective, New York: Springer 2018.

32 G. Lindegger \& C. Alberts, 'The dialogical self in the new South Africa', in: H. Hermans \& T. Gieser (red.), Handbook of Dialogical Self Theory, Cambridge: Cambridge University Press 2012, p. 215-234; C. Alberts, 'Afrikaner and Coloured School-Going Adolescents Negotiating Ethnic Identities in a Post-Colonial South African Educational Context', in: F. Meijers \& H. Hermans (red.), The dialogical self in education. A multicultural perspective, New York: Springer 2018. 
against terror omschreef als global apartheid. ${ }^{33}$ Volgens hem is de apartheid tegen zwarten in Zuid-Afrika afgeschaft in 1990, maar is de apartheid tegen moslims ervoor in de plaats gekomen sinds '9/11' in 2001. Dit wordt treffend verwoord door een moslima die in 1999 en in 2008 geïnterviewd werd: 'The world has changed tremendously in the last ten years, and that has affected me a lot personally. I grew up believing I was an Amsterdam-girl. But after 9/11 I became "a Muslim".34 In die zin is het bestrijden van extremisme niet veel anders dan het werken met verslaafde of depressieve mensen. Ook deze mensen hebben de neiging om zich te vereenzelvigen met één stem, terwijl hun positierepertoire potentieel veel groter is.

\section{Conclusie}

De Dialogical Self Theory laat zien dat extremisme, zoals het woord zelf al zegt, niet 'normaal' is. Het is een uitzondering op de regel. In de regel zijn mensen tot compromissen bereid en willen ze conflicten voorkomen of oplossen. Dit geldt ook voor verreweg de meeste moslims. ${ }^{35}$ Het is ook goed een onderscheid te maken tussen extremisme en geweld of gewelddadig extremisme. Niet achter elke salafist schuilt een gewelddadige terrorist. ${ }^{36}$ Slechts een kleine minderheid van de mensen die er extreme denkbeelden op nahouden, zijn bereid of in staat die denkbeelden te vertalen in gewelddadig gedrag. Women's Studies International Forum 2014, p. 30-37, m.n. p. 33.

35 J. Esposito \& D. Mogahed, Who speaks for Islam? What a billion Muslims really think, New York: Gallup Press 2007.

36 Zie verder J. Wagemakers, M. de Koning \& C. Becker, Salafisme. Utopische idealen in een weerbarstige praktijk, Almere: Parthenon 2014; S. Mekhennet, Ik moest alleen komen: Reizen naar het front van de Islam, Amsterdam: Nieuw Amsterdam 2017, een journalistiek verslag van gesprekken met 150 geradicaliseerde moslims dat een genuanceerd beeld laat zien van de radicale islam. 